\title{
NUTRITIONAL STATUS AND BODY COMPOSITION OF YOUNG ARTISTIC GYMNASTS FROM BULGARIA
}

\author{
Stefan Kolimechkov, Iliya Yanev, Iliya Kiuchukov, Lubomir Petrov, \\ Albena Alexandrova, Dilyana Zaykova, Emil Stoimenov \\ National Sports Academy „Vassil Levski”, Sofia, Bulgaria
}

\begin{abstract}
Young gymnasts should not have excessive body mass because that might lead to underperformance. Therefore, children practising gymnastics should consume a balanced diet, which will promote their physical abilities and optimal body mass. The aim of this study was to compare the nutrient intake of young Bulgarian artistic gymnasts to matched groups from the National Nutrition Survey in Bulgaria (NNSB2003). The study consisted of 76 artistic gymnasts (5 to 14 years of age) from four cities in Bulgaria, and the participants were divided into three groups in accordance with the age and gender categories applied in the NNSB2003. Anthropometric measurements were taken and a food frequency questionnaire was applied in order to assess the body composition and nutrient intake of the gymnasts. The percentile scores in the height and \%Fat of the gymnasts were significantly lower than the 50th percentile of the international norms. The energy intake of the gymnasts did not differ significantly from those reported in the NNSB2003, whilst the protein intake, relative protein intake, and energy contribution of proteins were significantly higher than those in the same survey. The energy contribution of fats was above the recommended norms (15-30\%), as provided by the WHO. The fat intake was slightly higher, and the carbohydrate intake was slightly lower than the recommended values in the literature, and, therefore, the former should be reduced and the latter increased in their food.
\end{abstract}

Key words: nutrition, diet, body composition, artistic gymnastics

\section{INTRODUCTION}

It is of particular importance to all athletes, young and old, to pay special attention to nutrition in order to achieve good results in sport (Nisevich, 2008). A good and balanced diet can support consistent intensive training, while reducing the risk of injuries. Furthermore, good food choices will also promote muscle adaptations in response to the training workload. (International Olympic Committee, 2012). The recommended nutrient intake in children and adolescents who are engaged in sports is different from those of non-athletes due to the additional physical exercise.

Artistic gymnastics is a strength sport which can be practised from an early age. It is recom- mended that young gymnasts should not have excessive body mass because that might lead to under-performance. Moreover, overweight can decrease the technique of the gymnasts and expose them to an increased risk of injuries due to the excess load on the body structure. (British Gymnastics, 2005). Therefore, children practising gymnastics should consume a balanced amount of proteins, carbohydrates and fats, which will help sustain and promote their physical abilities, as well as their optimal body mass.

Young athletes need a higher protein content than that recommended for non-athletes, but the studies conducted on children engaged in sports are scarce (Petrie et al., 2004). More- 
over, the reported data on protein intake in child athletes differ in the scientific literature. For instance, Cupisti et al. reported that the relative protein intake (RPI) of adolescents engaged in sports and a control group not similarly engaged is comparable $(1.09 \mathrm{~g} / \mathrm{kg}$ vs 1.13 $\mathrm{g} / \mathrm{kg}, p>0.05$ ) (Cupisti et al., 2002). Other authors recommend RPI of $1.0-1.5 \mathrm{~g} / \mathrm{kg}$ for children who have just begun a training programme, and $1.2-1.4 \mathrm{~g} / \mathrm{kg}$ for children who practise sports (Nevin-Folino, 2003, Nisevich, 2008). Dallas et al. recommend $\geq 1.5 \mathrm{~g} / \mathrm{kg}$ RPI for competitive female gymnasts (Dallas et al., 2017). However, other studies reported a higher amount of RPI, such as $1.6 \mathrm{~g} / \mathrm{kg}$ for children practising gymnastics (O'Connor, 2000), and 2-3 g/kg for young competitive gymnasts (Benardot et al., 1989). In our pilot study on nutrition of children engaged in gymnastics, the RPI was $3.2 \mathrm{~g} / \mathrm{kg}$ for those who were between the ages of 4 and 6 , and $2.9 \mathrm{~g} / \mathrm{kg}$ for those between the ages of 7 and 10 (Kolimechkov et al., 2016).

Studies on the nutrition of gymnasts (Benardot et al., 1989, Ersoy, 1991, Reggiani et al., 1989, Lindholm et al., 1995, Moffatt, 1984, Kirchner et al., 1995) showed that the energy contribution which comes from protein is either at the upper limit of the $10-15 \%$ recommended by the WHO, or above it (Karabudak et al., 2016, Kolimechkov et al., 2016, Benardot, 1996).

The American Dietetic Association (ADA) recommends the following relative carbohydrate intake (RCI) for young athletes: 3-5 g/ $\mathrm{kg}$ for very light intensity training; $5-8 \mathrm{~g} / \mathrm{kg}$ for moderate or heavy training; $8-9 \mathrm{~g} / \mathrm{kg}$ for pre-event loading (24-48 hours prior to the competition); $1.7 \mathrm{~g} / \mathrm{kg}$ for post-event refuelling, within 2-3 hours (Nevin-Folino, 2003, Nisevich, 2008). Carbohydrate food with a high glycaemic index should be consumed immediately following completion of training for best energy restoration results (British Gymnastics, 2005). Due to its importance as an energy supplier, carbohydrates should provide at least $50 \%$ of the energy intake in child athletes. For intensive training, the energy contribution from carbohydrates should increase to $65-70 \%$ (Petrie et al., 2004). However, many studies on the nutrient intake of gymnasts (Filaire and Lac, 2002, Reggiani et al., 1989, Benardot et al., 1989, Moffatt, 1984) reported that these athletes receive less than the recommended $55-75 \%$ energy intake from carbohydrates (WHO, 2003).

The following relative fat intake (RFI) of gymnasts is reported in the literature: $2.1 \pm 0.8$ $\mathrm{g} / \mathrm{kg}$ for 7-15-year-old gymnasts with energy contribution of $36.5 \pm 6.3 \%$ from the daily energy intake (Karabudak et al., 2016); $2.7 \pm 0.9$ $\mathrm{g} / \mathrm{kg}$ for 6-10-year-old gymnasts with energy contribution of $34.4 \pm 4.5 \%$ (Kolimechkov et al., 2016); and fat intake of $72.0 \pm 25.0 \mathrm{~g}$ for 13-16-year-old gymnasts with energy contribution of $32.0 \pm 4.0 \%$ (Lindholm et al., 1995). Other authors (Filaire and Lac, 2002, Reggiani et al., 1989, Benardot et al., 1989, Calabrese, 1985) also report that gymnasts consume above the recommended 15-30\% (WHO, 2003) of energy deriving from fat.

The aim of this study was to compare the energy and nutrient intakes of young Bulgarian artistic gymnasts to age- and gender-matched groups from the National Nutrition Survey for school children in Bulgaria, NNSB2003 (Petrova et al., 2003).

\section{METHODOLOGY \\ Participants}

The study consisted of 76 artistic gymnasts (43 girls and 33 boys) between the ages of five and fourteen, from four different cities in Bulgaria (Sofia, Blagoevgrad, Veliko Tarnovo and Ruse). The participants had on average 3.8 years of sports experience in artistic 
gymnastics (ranging from 1 to 10 years), and they regularly took part in, or were preparing for, competitions representing five gymnastic clubs which are registered with the Bulgarian Gymnastics Federation.

The participants were divided into three groups: Group-A (boys and girls from 5 to 9), Group-B (girls from 10 to 14), and Group-C (boys from 10 to 14), in accordance with the age and gender categories applied in the National Nutrition Survey for school children in Bulgaria, NNSB2003 (Petrova et al., 2003).

Institutional ethics approval for this research was granted by the National Sports Academy in Sofia, and informed consent was obtained from the parents of each gymnast.

\section{Body composition}

The height of the gymnasts was recorded to the nearest $0.1 \mathrm{~cm}$ using a height measure, body mass was recorded to within an accuracy of $0.1 \mathrm{~kg}$ by using the Omron BF511 electronic scale, and waist circumference was measured to the nearest $0.1 \mathrm{~cm}$ with the Lufkin W606PM tape measure. The anthropometric procedures for those measurements were followed thoroughly (Piwoz and Viteri, 1985, NHNES, 2007). Body mass index (BMI = body weight in $\mathrm{kg} /$ height in metres squared) and waist-toheight ratio ( $\mathrm{WHtR}=$ waist circumference in $\mathrm{cm} /$ height in $\mathrm{cm}$ ) were calculated, and the recommended cut-off of WHtR $=0.500$ was used to assess increased health risk in children relating to an excessive accumulation of body fat on the upper body (Ashwell and Hsieh, 2005, McCarthy and Ashwell, 2006). Moreover, the WHO AnthroPlus specialised software based on the international norms in children (WHO, 2011), as well as on the most recent Bulgarian norms as provided by the "Physical Development of Children and Youths in Bulgaria" study, PDCYB (Nacheva et al., 2012), were applied in order to calculate the percentile scores for height, weight and BMI of each gymnast. The following classification for the BMI percentile scores (PRs) in children and adolescents was applied: 'overweight' (BMI > $\left.85^{\text {th }} \mathrm{PRs}\right)$; 'obese' (BMI $\left.>97^{\text {th }} \mathrm{PRs}\right)$; 'thinness' (BMI $<15^{\text {th }} \mathrm{PRs}$ ); and 'severe thinness' (BMI $<3$ rd PRs), (WHO, 2007a).

In order to appropriately assess the body composition of gymnasts, body fat percentage (\%Fat) was also calculated. Two skinfolds (triceps and subscapular) were measured to an accuracy of $1 \mathrm{~mm}$ with the Lange Skinfold Calliper, Beta Technology Inc, Cambridge, USA, and the \%Fat was determined by the sum of the two skinfolds, using Slaughter's equations (Slaughter et al., 1988, Heyward and Stolarczyk, 1996). This method is highly recommended in literature to assess body composition in children and adolescents because of its accuracy and simplicity (Boye et al., 2002, ALPHA, 2009, Laurson et al., 2011). In addition, the percentile scores of $\%$ Fat were also calculated by using the international norms for Caucasian children and adolescents (McCarthy et al., 2006). The \%Fat was classified by the following cut-offs: 'overweight' (\%Fat $>$ $\left.85^{\text {th }} \mathrm{PRs} ;\right)$; 'obese' $\left(\%\right.$ Fat $\left.>95^{\text {th }}\right)$; and 'underfat' ( $\%$ Fat $\left.<2^{\text {nd }} P R s\right)$, (McCarthy et al., 2006).

\section{Nutritional assessment}

The food frequency questionnaire (FFQ), which had been used for children practising gymnastics (Kolimechkov et al., 2016), was applied in this study in order to assess the nutrient intake of the artistic gymnasts.

The FFQ consists of 30 questions relating to the weekly consumption of different types of food and questions about the physical activity, height and weight of children. In addition to that, tables for measuring the frequency of fruit and vegetable consumption were also added. The frequency tables included a total of 22 common fruits and 24 common vegetables with five possible answers for each fruit and vegetable (never, rarely, sometimes, often, 
and always). The FFQs were completed by the children's parents, which is a common practice when assessing nutrition in children and elderly people (Gibson, 1990).

Based on the results, the daily intake of proteins, carbohydrates and fats, relative protein intake per $\mathrm{kg}$ body mass (RPI), relative carbohydrate intake (RCI), relative fat intake (RFI), and the energy contribution of each nutrient $(\mathrm{E} \%)$, in addition to the total daily energy intake ( $\mathrm{kcal} / 24 \mathrm{~h})$ and relative energy intake (REN) were calculated. Moreover, the percent of protein and fat which comes from animal sources (animal protein $\%$ and animal fat $\%$ ) was also calculated.

The basal metabolic rate (BMR kcal/24h) was calculated by using the equations of HarrisBenedict (Harris and Benedict, 1919), which are commonly applied in research (Blinman and Cook, 2011).

The estimated daily energy needs ( $\mathrm{kcal} / 24 \mathrm{~h})$ were derived by employing the following formula (BMR kcal/24h x $(1.2+0.08 \times$ number of sessions)), (Harris and Benedict, 1919). The two lessons of physical education ( 2 x $45 \mathrm{~min}$ ) at school were considered as 1 sports session.

\section{Statistical Analysis}

The statistical analyses were conducted with SPSS Statistics 19 software, using descriptive statistics and One-way ANOVA with the Bonferroni post hoc test. Statistically significant differences between the average values were evaluated at $p<0.05$, and the data in the text and the tables are presented as mean \pm $\mathrm{SD}$, and in the figures are presented as mean \pm SE. In addition, one sample t-test and Cohen's effect size (d) of the percentile scores for the anthropometric parameters vs their $50^{\text {th }}$ percentile were calculated in order to present the magnitude of the effects. Pared samples t-test was used in order to compare the PRs scores of height, weight and BMI as calculated by the WHO norms vs the Bulgarian norms. Two sample t-test and Cohen's effect size of the nutrients and energy intake vs the data from the NNSB2003 were also calculated. The following classification of the effect size was applied: $\mathrm{d}(0.01)=$ very small, $\mathrm{d}(0.20)=$ small, $\mathrm{d}(0.50)$ $=$ medium, $\mathrm{d}(0.80)=$ large, $\mathrm{d}(1.20)=$ very large, and d (2.00) = huge (Sawilowsky, 2009, Cohen, 1988).

\section{RESULTS}

The anthropometric parameters, their percentile scores and their effect size vs the 50th percentiles (PRs) of the three groups are presented in Table 1. As expected, Group-A (5-9 years) has the smallest average sports experience (2.5 years). The average frequency of the gymnastics training ranged from 3 to 6 sessions per week and was significantly lower in the youngest group (5-9 years). The heightfor-age percentile scores in all groups were significantly lower than the 50th percentile of both international norms (WHO, 2006) and Bulgarian norms (Nacheva et al., 2012) for children and adolescents at this age (Table 1). The average weight PRs of the gymnasts did not differ from the average international standards in Group-A, but it was significantly lower than the Bulgarian norms in Group-A and Group-C. However, it should be taken into account that the World Health Organization (WHO) does not provide weight-for-age reference data for children over 10 years of age, because this indicator cannot distinguish between height and body mass at an age when many children are experiencing the pubertal growth spurt (WHO, 2007b). The percentile scores of the body mass index (BMI) for all three groups did not differ significantly from the $50^{\text {th }}$ PRs of the WHO and the Bulgarian norms, except for Group-A, and the average waist-to-height ratio was below the boundary of 0.500 , which distinguishes children at risk 
as far as their health is concerned (Ashwell cantly lower in the male group (Group-C) in and Hsieh, 2005, McCarthy and Ashwell, comparison with the female group (Group2006). The absolute value of $\%$ Fat is signifi- $\quad$ B). Overall, the $\%$ Fat percentile scores in all

Table 1. Anthropometric parameters, their percentile scores as provided by the international norms (WHO, 2011), and the Bulgarian norms (Nacheva et al., 2012), in addition to their effect size vs the $50^{\text {th }}$ percentile (PRs) of the artistic gymnasts (mean $\left.\pm S D\right)$.

\begin{tabular}{|c|c|c|c|}
\hline & $\begin{array}{c}\text { 5-9 years } \\
(\mathrm{n}=45) \\
\text { Group-A }\end{array}$ & $\begin{array}{c}\text { 10-14 years } \\
\text { Female }(\mathrm{n}=18) \\
\text { Group-B }\end{array}$ & $\begin{array}{c}\text { 10-14 years } \\
\text { Male }(\mathrm{n}=13) \\
\text { Group-C }\end{array}$ \\
\hline Age (years) & $7.93 \pm 1.26 \mathrm{BC}$ & $12.01 \pm 1.56$ & $12.22 \pm 1.60$ \\
\hline Sports experience (months) & $30.22 \pm 18.57 \mathrm{BC}$ & $63.42 \pm 38.74$ & $71.69 \pm 25.95$ \\
\hline Sessions per week & $4.17 \pm 1.16^{\mathrm{b}} \mathrm{C}$ & $5.22 \pm 1.06$ & $5.54 \pm 0.78$ \\
\hline Height $(\mathrm{cm})$ & $122.96 \pm 8.79 \mathrm{BC}$ & $146.96 \pm 10.15$ & $146.38 \pm 9.43$ \\
\hline $\begin{array}{l}\text { Height WHO percentile score } \\
\text { Effect size vs } 50^{\text {th }} \text { PRs }\end{array}$ & $\begin{array}{c}32.49 \pm 29.54 \\
0.59 \mathrm{D}\end{array}$ & $\begin{array}{c}36.35 \pm 26.66 \\
0.51 \mathrm{~d}\end{array}$ & $\begin{array}{l}29.50 \pm 21.86 \\
0.94^{\mathrm{d}}\end{array}$ \\
\hline Height BG percentile score & $23.31 \pm 26.58 \mathrm{~W}$ & $33.87 \pm 25.13$ & $24.52 \pm 19.42 \mathrm{w}$ \\
\hline Effect size vs $50^{\text {th }}$ PRs & $1.00 \mathrm{D}$ & $0.64 \mathrm{~d}$ & $1.31 \mathrm{D}$ \\
\hline Weight (kg) & $25.09 \pm 5.21 \mathrm{BC}$ & $40.03 \pm 9.62$ & $38.90 \pm 8.06$ \\
\hline $\begin{array}{l}\text { Weight WHO percentile score } \\
\text { Effect size vs } 50^{\text {th }} \text { PRs }\end{array}$ & $\begin{array}{c}43.56 \pm 27.51 \\
\text { NS }\end{array}$ & $-*$ & $-*$ \\
\hline $\begin{array}{l}\text { Weight BG percentile score } \\
\text { Effect size vs } 50^{\text {th }} \text { PRs }\end{array}$ & $\begin{array}{c}35.35 \pm 26.66 \mathrm{~W} \\
0.55 \mathrm{D}\end{array}$ & $\begin{array}{c}43.03 \pm 25.67 \\
\mathrm{NS}\end{array}$ & $\begin{array}{c}37.26 \pm 15.83 \\
0.80 \mathrm{~d}\end{array}$ \\
\hline $\operatorname{BMI}\left(\mathrm{kg} / \mathrm{cm}^{2}\right)$ & $16.43 \pm 1.82$ & $18.26 \pm 2.24$ & $17.97 \pm 1.65$ \\
\hline BMI WHO percentile score & $57.50 \pm 25.88$ & $50.67 \pm 23.09$ & $51.05 \pm 22.18$ \\
\hline Effect size vs $50^{\text {th }}$ PRs & NS & NS & NS \\
\hline BMI BG percentile score & $59.85 \pm 23.26 \mathrm{w}$ & $59.61 \pm 23.91 \mathrm{~W}$ & $56.16 \pm 19.53$ \\
\hline Effect size vs $50^{\text {th }}$ PRs & $0.42^{\mathrm{d}}$ & NS & NS \\
\hline Waist-to-height ratio & $0.44 \pm 0.04^{b}$ & $0.41 \pm 0.03$ & $0.43 \pm 0.02$ \\
\hline$\%$ Fat & $15.30 \pm 3.97$ & $16.77 \pm 3.93 \mathrm{c}$ & $12.63 \pm 2.48$ \\
\hline$\%$ Fat percentile score & $16.00 \pm 22.71$ & $12.31 \pm 13.67$ & $9.92 \pm 15.76$ \\
\hline Effect size vs $50^{\text {th }}$ PRs & $1.50 \mathrm{D}$ & $2.76 \mathrm{D}$ & $2.54 \mathrm{D}$ \\
\hline
\end{tabular}

* WHO does not provide weight-for-age reference data for children older than 10 years of age (WHO, 2007b).

${ }^{b}-p<0.01$ vs Group- $B ; B-p<0.001$ vs Group- $B$;

$c-p<0.05$ vs Group $-C ; C-p<0.001$ vs Group $-C$;

$d-p<0.05$ vs $50^{\text {th }} P R s ;{ }^{d}-p<0.01$ vs $50^{\text {th }} P R s ; D-p<0.001$ vs $50^{\text {th }} P R s$;

$w-p<0.05$ vs WHO PRs norms; $W-p<0.001$ vs WHO PRs norms;

NS - not significant 
Table 2. Daily intake of macronutrients and energy contribution of each nutrient (E\%) of the gymnasts' diet (mean $\pm S D$ ), in addition to their effect size vs the data from the National Nutrition Survey in Bulgaria (NNSB2003).

\begin{tabular}{|c|c|c|c|}
\hline & $\begin{array}{c}\text { 5-9 years } \\
(\mathrm{n}=45) \\
\text { Group-A }\end{array}$ & $\begin{array}{c}\text { 10-14 years } \\
\text { Female }(\mathrm{n}=18) \\
\text { Group-B }\end{array}$ & $\begin{array}{c}\text { 10-14 years } \\
\text { Male }(\mathrm{n}=13) \\
\text { Group-C }\end{array}$ \\
\hline Energy needs (kcal/24h) & $1865.16 \pm 258.72 \mathrm{BC}$ & $2405.11 \pm 274.59$ & $2500.92 \pm 348.44$ \\
\hline $\begin{array}{l}\text { Relative energy needs (REN) } \\
(\mathrm{kcal} / \mathrm{kg} / 24 \mathrm{~h})\end{array}$ & $75.53 \pm 9.17 \mathrm{~B}^{\mathrm{c}}$ & $62.31 \pm 10.14$ & $65.11 \pm 5.18$ \\
\hline Energy intake (kcal/24h) & $1950.80 \pm 460.17$ & $2181.45 \pm 595.12$ & $2301.00 \pm 640.96$ \\
\hline Effect size & NS & NS & NS \\
\hline $\begin{array}{l}\text { Relative energy intake (REI) } \\
(\mathrm{kcal} / \mathrm{kg} / 24 \mathrm{~h})\end{array}$ & $79.72 \pm 21.57 \mathrm{~B}^{\mathrm{c}}$ & $56.23 \pm 15.78$ & $59.60 \pm 12.52$ \\
\hline Energy needs/Energy intake & $1.06 \pm 0.28$ & $0.91 \pm 0.25$ & $0.92 \pm 0.20$ \\
\hline Protein (g/24h) & $\begin{array}{c}77.72 \pm 16.19 \\
1.10 \mathrm{D}\end{array}$ & $\begin{array}{c}84.86 \pm 21.37 \\
1.05 \mathrm{D}\end{array}$ & $\begin{array}{c}88.29 \pm 28.27 \\
0.77^{\mathrm{d}}\end{array}$ \\
\hline $\begin{array}{l}\text { Relative protein intake }(\mathrm{RPI}) \\
(\mathrm{g} / \mathrm{kg} / 24 \mathrm{~h})\end{array}$ & $3.20 \pm 0.87 \mathrm{~B}^{\mathrm{c}}$ & $2.19 \pm 0.58$ & $2.28 \pm 0.56$ \\
\hline Effect size & $1.45 \mathrm{D}$ & $1.13 \mathrm{D}$ & $0.97 \mathrm{D}$ \\
\hline Protein-E\% & $16.60 \pm 1.80$ & $16.11 \pm 2.00$ & $15.69 \pm 2.14$ \\
\hline Effect size & $2.06 \mathrm{D}$ & $1.78 \mathrm{D}$ & $1.66 \mathrm{D}$ \\
\hline Fat $(g / 24 h)$ & $69.13 \pm 16.63$ & $77.55 \pm 25.89$ & $77.30 \pm 21.90$ \\
\hline Effect size & NS & NS & NS \\
\hline $\begin{array}{l}\text { Relative fat intake (RFI) } \\
(\mathrm{g} / \mathrm{kg} / 24 \mathrm{~h})\end{array}$ & $2.83 \pm 0.79$ & $2.01 \pm 0.73$ & $2.00 \pm 0.44$ \\
\hline Fat-E\% & $33.11 \pm 5.34$ & $32.72 \pm 6.32$ & $31.15 \pm 4.60$ \\
\hline Effect size & $0.37 \mathrm{~d}$ & NS & NS \\
\hline Carbohydrates (g/24h) & $243.58 \pm 74.44$ & $275.08 \pm 91.14$ & $300.74 \pm 94.61$ \\
\hline Effect size & NS & NS & NS \\
\hline $\begin{array}{l}\text { Relative carbohydrates intake } \\
(\mathrm{RCI}),(\mathrm{g} / \mathrm{kg} / 24 \mathrm{~h})\end{array}$ & $9.92 \pm 3.26^{b}$ & $7.07 \pm 2.34$ & $7.81 \pm 2.04$ \\
\hline Carbohydrates-E\% & $50.40 \pm 6.01$ & $51.06 \pm 7.26$ & $53.15 \pm 6.12$ \\
\hline Effect size & NS & NS & NS \\
\hline Animal Protein (\%) & $53.13 \pm 8.49$ & $52.28 \pm 10.68$ & $50.69 \pm 11.68$ \\
\hline Effect size & $0.78 \mathrm{D}$ & $0.70^{\mathrm{d}}$ & $0.68 \mathrm{~d}$ \\
\hline Animal Fat $(\%)$ & $64.44 \pm 10.81$ & $66.56 \pm 14.55$ & $62.38 \pm 16.30$ \\
\hline
\end{tabular}

${ }^{b}-p<0.01$ vs Group- $B ; B-p<0.001$ vs Group- $B$;

${ }^{c}-p<0.01$ vs Group-C; $C-p<0.001$ vs Group-C;

$d-p<0.05$ vs NNSB2003; ${ }^{d}-p<0.01$ vs NNSB2003; $D-p<0.001$ vs NNSB2003;

$N S$ - not significant 
groups were substantially lower than the 50th percentile of the international norms for children and adolescents (McCarthy et al., 2006), and Cohen's effect size was very large $(d=$ 1.50) for Group-A, and huge for Group-B and Group-C $(d=2.76$ and $d=2.54$, respectively), in accordance with the benchmarks provided by Cohen and Sawilowsky (Sawilowsky, 2009, Lakens, 2013).

The data from the nutritional survey for all three groups are presented in Table 2. The average REN and REI values in Group-A were significantly higher than those in the other two groups. The daily energy intake in all groups did not differ from those reported in the National Nutrition Survey, 2003, in Bulgarian school children (NNSB2003), (Table 3). However, the protein intake, RPI, and the energy contribution of proteins were significantly higher in the artistic gymnasts in comparison with those published in the NNSB2003 for children and adolescents of the same gender and at the same age. The effect size of these differences according to Sawilowsky and Cohen (Sawilowsky, 2009, Cohen, 1988) varied from 0.77 (large) to 2.06 (huge). In addition to that, Group-A had a significantly higher RPI of approximately $1 \mathrm{~g} / \mathrm{kg} / 24 \mathrm{~h}$, compared to Group-B and Group-C.

The fat and carbohydrate intake, as well as the energy contribution from those macronutrients, did not differ from those of the NNSB2003, except in the Fat-E\%, which was higher in Group-A, where there was a small effect size $(d=0.37)$. The protein and fat which come from animal sources did not show any significant differences between the three groups. However, the protein which comes from animal sources was significantly higher than the NNSB2003 data, with medium effect size ( $d=0.78$ for Group-A, $d=0.70$ for GroupB and $d=0.68$ for Group-C).

Table 3. Daily intake of macronutrients and \% of energy (E\%) in school children from the National Nutrition Survey in Bulgaria, NNSB2003 (Petrova et al., 2003) (mean \pm SD)

\begin{tabular}{rccc}
\hline & $\begin{array}{c}\mathbf{7 - 9} \text { years } \\
\text { Female and Male } \\
(\mathbf{n = 8 8 8})\end{array}$ & $\begin{array}{c}\mathbf{1 0 - 1 4} \text { years } \\
\text { Female } \\
(\mathbf{n = 8 5 3})\end{array}$ & $\begin{array}{c}\mathbf{1 0 - 1 4} \text { years } \\
\text { Male } \\
(\mathbf{n = 8 6 1})\end{array}$ \\
\hline Energy $(\mathrm{kcal} / 24 \mathrm{~h})$ & $1853 \pm 713.0$ & $2056 \pm 792.0$ & $2313 \pm 915.0$ \\
Protein $(\mathrm{g} / 24 \mathrm{~h})$ & $53.4 \pm 22.3$ & $59.1 \pm 24.6$ & $67.1 \pm 27.5$ \\
Relative protein intake & $1.9 \pm 0.9$ & $1.4 \pm 0.7$ & $1.6 \pm 0.7$ \\
Protein $(\mathrm{kg} / 24 \mathrm{~h})$ & $11.5 \pm 2.5$ & $11.5 \pm 2.6$ & $11.7 \pm 2.4$ \\
Fat $(\mathrm{g} / 24 \mathrm{~h})$ & $76.7 \pm 38.4$ & $85.2 \pm 42.9$ & $93.0 \pm 47.7$ \\
Fat $(\mathrm{E} \%)$ & $36.3 \pm 8.7$ & $36.4 \pm 8.6$ & $35.4 \pm 8.9$ \\
Carbohydrates $(\mathrm{g} / 24 \mathrm{~h})$ & $237.2 \pm 91.8$ & $262.8 \pm 100.7$ & $301.6 \pm 120.5$ \\
Carbohydrates $(\mathrm{E} \%)$ & $52.0 \pm 9.1$ & $51.8 \pm 9.1$ & $52.8 \pm 9.3$ \\
Animal Protein $(\%)$ & $38.5 \pm 19.2$ & $39.0 \pm 19.2$ & $38.4 \pm 18.1$ \\
\hline
\end{tabular}

The average frequency consumption of fruits and vegetables did not differ significantly between the three groups of gymnasts. Therefore, the results of fruit and vegetable consumption of all three groups of gymnasts were combined together and are presented in Figure 1 and Figure 2, respectively. 


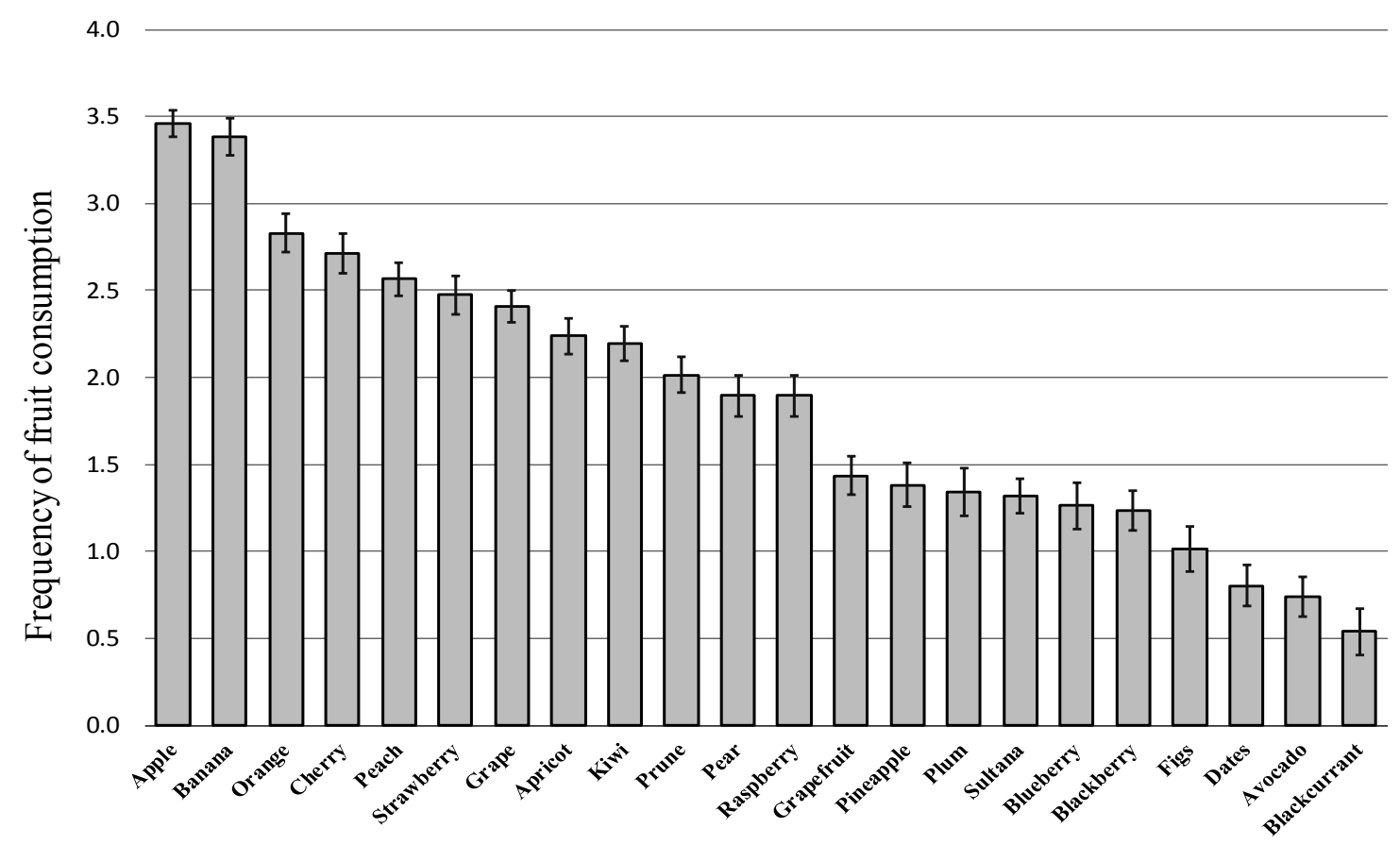

Figure 1. Frequency of fruit consumption of all artistic gymnasts $(n=76)$

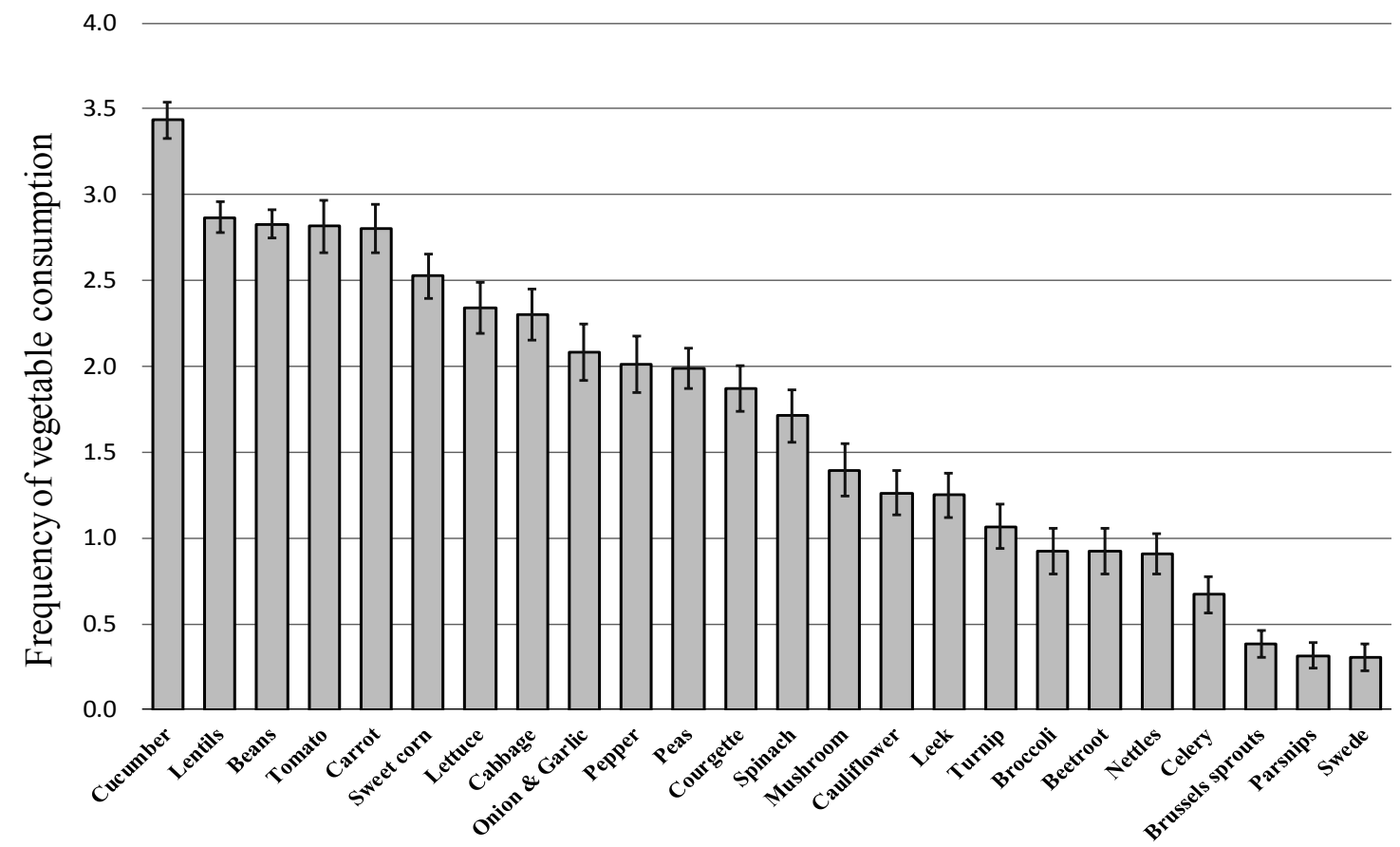

Figure 2. Frequency of vegetable consumption of all artistic gymnasts ( $n=76)$

The most often consumed fruits were banan- artistic gymnasts (50\%) did not meet the minias and apples, and the most frequently consumed mum recommendation of $400 \mathrm{~g}$ or 5 portions vegetables were cucumbers, lentils, beans, to- (standard portion weighs about $80 \mathrm{~g}$ ) of fruits and matoes and carrots. The results from our survey, vegetables a day, provided by the World Health presented in Figure 3, showed that 38 out of 76 Organization (Agudo, 2004, WHO, 2003). 


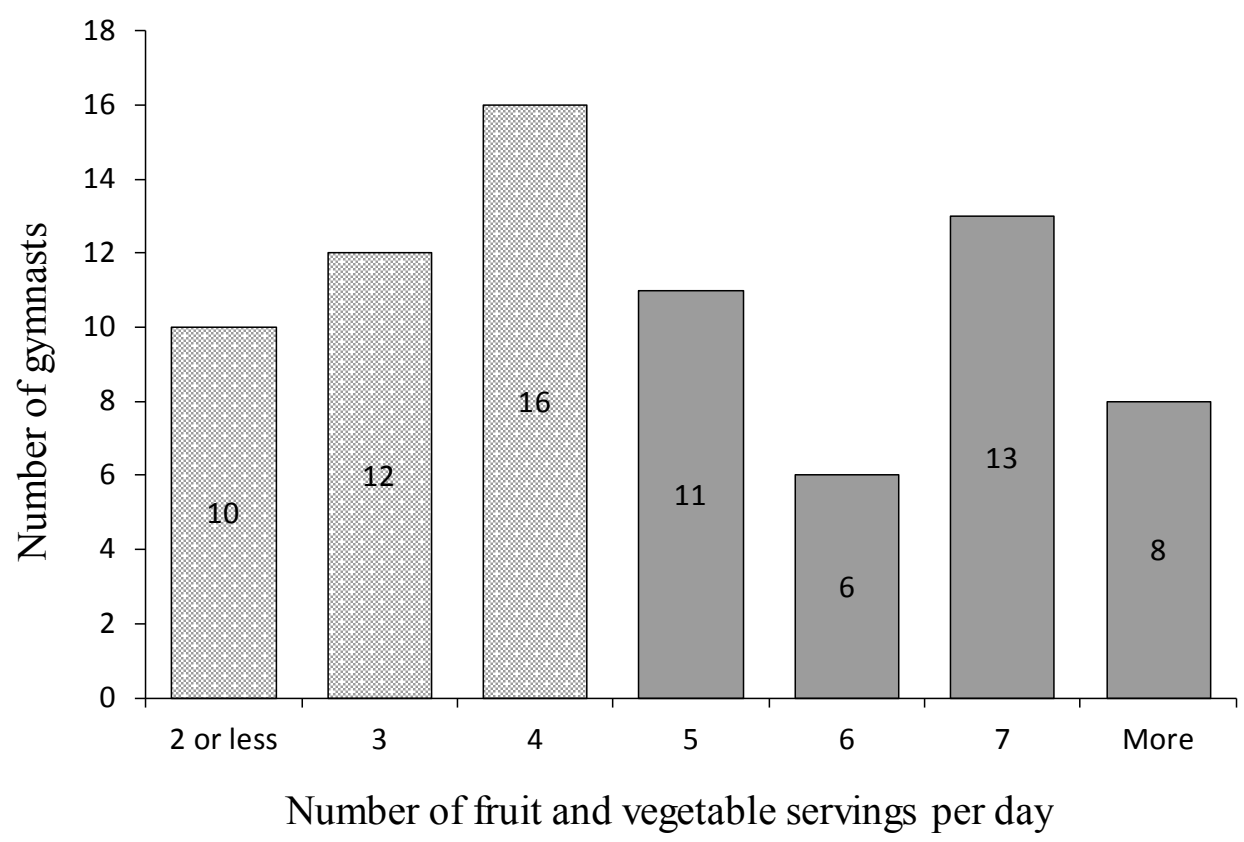

Figure 3. Fruit and vegetable intake $(1$ portion $=80 \mathrm{~g})$ of all artistic gymnasts $(n=76)$

\section{DISCUSSION}

The percentile scores in the height of the gymnasts are significantly lower than the $50^{\text {th }}$ percentile of both international and Bulgarian norms (Table 1), with medium to large effect size for Group-A (Cohen's $d=0.59$ and 1.00, respectively), medium effect size for GroupB (Cohen's $d=0.51$ and 0.64 , respectively), and large effect size for Group-C (Cohen's $d$ $=0.94$ and 1.31 , respectively). The gymnasts with shorter stature probably have an advantage while executing gymnastics exercises. The absolute average values of the height of young gymnasts in different studies (Benardot, 2014) are similar to those in our study. Another example can be seen in the heightfor-age of female junior elite gymnasts, which progressively dropped from the 48th to the 20th percentile as age increased (Benardot and Czerwinski, 1991). These results do not signify a slowdown in growth as a result of artistic gymnastics training. Malina et al. (2013) in their review, which analysed the role of intensive training on the growth of artistic gymnasts, came to the conclusion that adult height or near adult height of artistic gymnasts of both genders is not compromised by intensive gymnastics training at a young age or during the pubertal growth spurt (Malina et al., 2013). Sands (1999) recognises gymnastics to be a unique area of physical activity which, unlike many sports which favour athletes of greater stature or weight, provides opportunities for even the smallest and lightest athletes in the area of competitive activities (Sands, 1999).

The BMI percentile scores in all groups did not differ from the $50^{\text {th }}$ percentile of the international norm, but they did not provide an accurate assessment for some individual gymnasts involved in our study because of the limitations of the BMI. It should be stated that the BMI provides a simple way, employing a standardised methodology, to assess and monitor the health of school children (Boeva and Marinova, 2013, Boeva and Margaritova, 2014), in addition to providing a safe, inexpensive, and widely applied anthropometric method (Pekar, 2011, Keys et al., 2014). However, the BMI does not distinguish between fat and muscle mass, and, therefore, some authors maintain 
that this specific parameter is not appropriate for some groups of people, such as professional athletes, body building enthusiasts, people engaged in jobs with strenuous physical activity (Bogin and Varela-Silva, 2012), and adolescent athletes (Lutoslawska et al., 2014).

The $\%$ Fat percentile scores in all groups were significantly lower than the $50^{\text {th }}$ percentile $(p<0.001)$ with very large to huge effect size, which is normal for children and adolescents who are engaged in artistic gymnastics (Jemni, 2011). Our results are also similar to those reviewed by Benardot (Benardot, 2014), where the average $\%$ Fat for young female and male gymnasts ranged between $8.6 \%$ and $21.5 \%$.

The energy intake of the gymnasts from all groups did not differ significantly from those reported in the national survey, NNSB2003. The REI of Group-A was significantly higher than the older gymnasts (Group-B and Group-C) by about $20 \mathrm{kcal} / \mathrm{kg}$, which is probably because of the increased energy needs for growth at this age. There is a good consistency between the REN and REI in all groups, as can be seen from their ratio, which is close to 1 (Table 2).

The protein intake and the relative protein intake (RPI) were both significantly higher $(p<0.001)$ than those published in the NNSB2003. This higher protein intake is in line with our previous study (Kolimechkov et al., 2016) and with other authors who reported higher values of RPI for young competitive gymnasts (Benardot et al., 1989, Karabudak et al., 2016). Consequently, the energy contribution of proteins was significantly higher than the NNSB2003 and the values of 10$15 \%$, as recommended by the WHO (WHO, 2003), but this was in line with data reported for gymnasts (Benardot, 1996, Benardot et al., 1989, Karabudak et al., 2016, Kirchner et al., 1995). Although half of the consumed protein by the gymnasts in our study comes from animal sources, a recent review concluded that a well-planned vegan diet is also capable of fulfilling the protein needs of competitive gymnasts, in addition to helping them lose excess weight, improving the quality of diet, and at the same time reducing the risk of modern chronic diseases in the long term (Jakše and Jakše, 2018).

The fat and carbohydrate intake, as well as the energy contribution did not differ from those reported in the NNSB2003, except for the energy contribution of fats in GroupA, which was slightly lower. Overall in all groups, the energy contribution of fats was above the recommended norms (15-30\%), as provided by the WHO (WHO, 2003). The reported data in literature show similar findings in line with our results: the energy contribution of fats for gymnasts is above the recommended $15-30 \%$, and that of carbohydrates is below 55-75\% (Karabudak et al., 2016, Benardot et al., 1989, Reggiani et al., 1989, Kirchner et al., 1995, Moffatt, 1984, Kolimechkov et al., 2016). It has been suggested that children seem to be more suited to absorbing free fatty acids as a primary substrate for exercise compared with carbohydrates (Unnithan and Goulopoulou, 2004). However, after reviewing multiple studies on nutrition for young gymnasts, Benardot (2014) highlights that they should increase the energy contribution of carbohydrates and lower their fat intake, as a diet high in carbohydrates, with a moderate amount of protein, and with a low fat content, will provide the best combination for those athletes (Benardot, 2014).

The gymnasts from our study predominantly consumed non-seasonal fruits, such as apples, bananas and citrus fruits, as well as vegetables which are traditional in Bulgaria: cucumbers, tomatoes and carrots, and highin-protein lentils and beans. However, 50\% 
of all artistic gymnasts had a low intake of fruits and vegetables, which was below the minimum figure of $400 \mathrm{~g}$ or 5 portions, as recommended by the WHO (Agudo, 2004, WHO, 2003).

\section{CONCLUSIONS}

The results showed that the height percentile scores of the gymnasts were significantly lower than the 50th percentile of both international and Bulgarian norms. The $\%$ Fat and its percentile scores showed substantially low levels for all three groups, which are within the norms and parameters for artistic gymnasts.

The energy intake of the artistic gymnasts did not differ significantly from those reported in the Bulgarian nutritional survey, NNSB2003. However, the protein intake, the relative protein intake (RPI), and the energy contribution of proteins were significantly higher than those for children and adolescents from the national survey, but were in line with other nutritional studies on gymnasts. The fat intake was slightly higher, and the carbohydrate intake was slightly lower than the recommended values in literature. Therefore, the carbohydrate intake should be increased, and the fat content in their food reduced. Gymnasts should increase their fruit and vegetable intake to at least five portions a day, as recommended by the WHO.

\section{ACKNOWLEDGMENT}

This research was financially supported by Grant '08/15.02.2018' from the National Sports Academy, Sofia, Bulgaria.

\section{REFERENCES}

Agudo, A. (2004). Measuring intake of fruit and vegetables. FAO and WHO workshop on fruit and vegetables for health. Kobe, Japan: World Health Organization.

Alpha (2009). The Alpha Health-related Fitness Test battery for Children and Adolescents,

\section{Test Manual.}

Ashwell, M. \& Hsieh, S. D. (2005). Six reasons why the waist-to-height ratio is a rapid and effective global indicator for health risks of obesity and how its use could simplify the international public health message on obesity. Int J Food Sci Nutr, 56, pp. 303-7.

Benardot, D. (1996). Working with young athletes: views of a nutritionist on the sports medicine team. Int J Sport Nutr, 6, pp. 110-20.

Benardot, D. (2014). Gymnastics. In: Maughan, R. (ed.) Sports Nutrition: The Encyclopedia of Sports Medicine London: IOC Medical Commission Publication.

Benardot, D. \& Czerwinski, C. (1991). Selected body composition and growth measures of junior elite gymnasts. Journal of the American Dietetic Association, 91, pp. 29-33.

Benardot, D., Schwarz, M. \& D., H. (1989). Nutrient intake in young, highly competitive gymnasts. Journal of the American Dietetic Association, 89, pp. 401-3.

Blinman, T. \& Cook, R. (2011). Allometric Prediction of Energy Expenditure in Infants and Children. ICAN: Infant, Child, \& Adolescent Nutrition, 3, pp. 216-224.

Boeva, S. \& Margaritova, V. (2014). Impact of BMI on the manifestation of physical fitness with students from primary school age. Prospects in education, The Plovdiv University "Paisii Hilendarski”. Plovdiv, Bulgaria. ISBN 978-954-423-942-8.

Boeva, S. \& Marinova, D. (2013). Should BMI be considered as part of the assessment in Physical Education for school pupils. European standards in sport education at schools. V. Tarnovo, Bulgaria: I \& B, ISBN: 978-954-9689-79-2.

Bogin, B. \& Varela-silva, I. (2012). The Body Mass Index: the good, the bad and the horrid. Bulletin de la Societe Suisse d'Anthropologie, 18, pp. 5-11.

Boye, K. R., T. Dimitriou, F. Manz, E. 
Schoenau, C. Neu, S. Wudy \& Remer, T. (2002). Anthropometric assessment of muscularity during growth: estimating fat-free mass with 2 skinfold-thickness measurements is superior to measuring midupper arm muscle area in healthy prepubertal children. The American Journal of Clinical Nutrition, 76, pp. 628-632.

British Gymnastics (2005). Health, Safety and Welfare Policy, Newport, UK.

Calabrese, L. H. (1985). Nutritional and medical aspects of gymnastics. Clin Sports Med, 4, pp. 23-30.

Cohen, J. (1988). Statistical Power Analysis for the Behavioral Sciences, USA, Lawrence Erlbaum Associates.

Cupisti, A., D’Alessandro, C., Castrogiovanni, S., Barale, A. \& Morelli, E. (2002). Nutrition knowledge and dietary composition in Italian adolescent female athletes and nonathletes. Int J Sport Nutr Exerc Metab, 12, pp. 207-19.

Dallas, G., Dallas, C., Simatos, E. \& Simatos, J. (2017). Nutritional recommendations and guidelines for women in gymnastics: Current aspects and critical interventions. Science of Gymnastics Journal, 9, pp. 27-40.

Ersoy, G. (1991). Dietary status and anthropometric assessment of child gymnasts. $J$ Sports Med Phys Fitness, 31, pp. 577-80.

Filaire, E. \& Lac, G. (2002). Nutritional status and body composition of juvenile elite female gymnasts. The Journal of sports medicine and physical fitness, 42, pp. 65-70.

Gibson, R. S. (1990). Principles of nutritional assessment, Oxford, Oxford University Press.

Harris, J. \& Benedict, F. (1919). A Biometric Study of Basal Metabolism in Man, Washington DC, Carnegie Institute of Washington.

Heyward, V. H. \& Stolarczyk, L. M. (1996). Applied Body Composition Assessment, USA, Human Kinetics.
International Olympic Committee (2012). Nutrition for athletes. A practical guide to eating for health and performance.

Jakše, B. \& Jakše, B. (2018). Is vegan diet appropriate for competitive artistic gymnasts? Science of Gymnastics Journal, 10, pp. 153-178.

Jemni, M. (2011). The Science of Gymnastics, London, UK, Routledge.

Karabudak, E., Koksal, E., Ertaş, Y. \& Kucukerdonmez, O. (2016). Dietary intake of Turkish gymnast and non-gymnast children. Nutrition \& Dietetics, 73, pp. 184-189.

Keys, A., Fidanza, F., Karvonen, M. J., Kimura, N. \& Taylor, H. L. (2014). Indices of relative weight and obesity. Int J Epidemiol, 43, pp. 655-65.

Kirchner, E. M., Lewis, R. D. \& O’Connor, P. J. 1995. Bone mineral density and dietary intake of female college gymnasts. Med Sci Sports Exerc, 27, pp. 543-9.

Kolimechkov, S., Petrov, L., Alexandrova, A. \& Atanasov, P. (2016). Nutrition and physical development assessment of pre-school and primary school children practising artistic gymnastics African Journal for Physical Activity and Health Sciences (AJPHES), 22, pp. 565-577.

Lakens, D. (2013). Calculating and reporting effect sizes to facilitate cumulative science: a practical primer for t-tests and ANOVAs. Front Psychol, 4, pp. 863.

Laurson, K. R., Eisenmann, J. C. \& Welk, G. J. (2011). Body fat percentile curves for U.S. children and adolescents. American Journal of Preventive Medicine, 41, pp. S87-92.

Lindholm, C., K. Hagenfeldt \& Hagman, U. (1995). A nutrition study in juvenile elite gymnasts. Acta Pediatr, 84, pp. 273-7.

Lutoslawska, G., M. Malara, P. Tomaszewski, K. Mazurek, A. Czajkowska, A. Keska \& Tkaczyk, J. (2014). Relationship between the percentage of body fat and surrogate indices of fatness in male and female Polish active and 
sedentary students. Journal of Physiological Anthropology, 33.

Malina, R. M., Baxter-Jones, A. D., Armstrong, N., Beunen, G. P., Caine, D., Daly, R. M., Lewis, R. D., Rogol, A. D. \& Russell, K. (2013). Role of intensive training in the growth and maturation of artistic gymnasts. Sports Med, 43, pp. 783-802.

Mccarthy, H. D. \& Ashwell, M. (2006). A study of central fatness using waist-to-height ratios in UK children and adolescents over two decades supports the simple message--'keep your waist circumference to less than half your height'. Int J Obes (Lond), 30, pp. 988-92.

Mccarthy, H. D., T.J. Cole, T. Fry, S.A. Jebb \& Prentice, A. M. (2006). Body fat reference curves for children. International journal of Obesity, 30, pp. 598-602.

Moffatt, R. J. (1984). Dietary status of elite female high school gymnasts: inadequacy of vitamin and mineral intake. J Am Diet Assoc, 84, pp. 1361-3.

Nacheva, A., Zhecheva, Y., Yankova, I., Filcheva, Z., Mitova, Z. \& Yordanov, Y. (2012). Physical Development of Children and Youths in Bulgaria on the borderline between 20th and 21st century, Academic Publishing House 'Prof. Marin Drinov'.

Nevin-folino, N. (2003). Pediatric Manual of Clinical Dietetics (2nd ed.). The Pediatric Nutrition Practice Group. Chicago: American Dietetic Association.

Nhnes (2007). National Health and Nutrition Examination survey (NHNES). Anthropometry procedures manual, USA, CDC.

Nisevich, P. (2008). Sports Nutrition for Young Athletes. IDEA Fitness Journal, pp. 65-67.

O'Connor, H. (2000). Special needs: children an adolescents in sport. In: Burke, L. M. \& Deakin, V. (eds.) Clinical Sports Nutrition. Sydney: McGraw Hill.

Pekar, T. (2011). Body Mass Index. IMS
Magazine, Summer 2011, pp. 21-22.

Petrie, H., E. Stover \& Horswill, C. (2004). Nutritional Concerns for the Child and Adolescent Competitor. Nutrition, 20, pp. 620-631.

Petrova, S., L. Ivanova, D. Baikova, K. Angelova, B. Iordanov, V. Duleva, D. Ovcharova \& Vatralova, K. (2003). National Survey on nutrition and nutritional status of schoolchildren in Bulgaria (Report). (in Bulgarian). Bulgaria: National Center of Hygiene, Medical Ecology and Nutrition.

Piwoz, G. \& Viteri, F. (1985). Food and Nutrition Bulletin. UNU, 07, 86.

Reggiani, E., Arras, G. B., Trabacca, S., Senarega, D. \& Chiodini, G. (1989). Nutritional status and body composition of adolescent female gymnasts. J Sports Med Phys Fitness, 29, pp. 285-8.

Sands, W. (1999). Why Gymnastics? USA Gymnastics Online: Technique, pp. 19.

Sawilowsky, S. (2009). New Effect Size Rules of Thumb. Journal of Modern Applied Statistical Methods, 8, pp. 597-599.

Slaughter, M., T. Lohman, R. Boileau, C. Horswill, R. Stillman, M. Van loan \& Bemben, D. (1988). Skinfold equations for estimation of body fatness in children and youth. Human biology, 60, pp. 709-23.

Unnithan, V. \& Goulopoulou, S. 2004. Nutrition for the Pediatric Athlete. Current Sports Medicine Reports, 3, pp. 206-2011.

WHO (2003). Diet, Nutrition and the Prevention of Chronic Disease. Report of a Joint WHO/FAO Expert Consultation. Chapter 5: Population nutrient intake goals for preventing chronic-diseases. Geneva: World Health Organization 2003.

WHO (2006). WHO Child Growth Standards based on length/height, weight and age. Acta Paediatr Suppl, 450, pp. 76-85.

WHO. (2007)a. BMI-for-age (5-19 years) [Online]. World Health Organization. Available: http://www.who.int/growthref/who2007 
bmi_for_age/en/ [Accessed accessed on 19 cessed on 19 February 2019].

February 2019].

WHO. (2007)b. Weight-for-age (5-19 years) [Online]. World Health Organization. Available: http://www.who.int/growthref/ who2007_weight_for_age/en/[Accessed ac-
WHO (2011). WHO Anthro for personal computers, version 3.2.2, 2011: Software for assessing growth and development of the world's children. Geneva: WHO, 2010.

\section{Corresponding author:}

Stefan Kolimechkov

National Sports Academy ,Vassil Levski” Studentski grad, 21, Acad. Stefan Mladenov Str.

Sofia 1700, Bulgaria

E-mail: dr.stefan.kolimechkov@gmail.com 